\title{
Det förflutna är ett främmande land. Medierade minnen av Jugoslavien i postjugoslavisk dokumentärfilm
}

\author{
Critica litterarum Lundensis 17 \\ Sanjin Pejković \\ Lund: Lunds Universitet, 2019 \\ 361 sider. ISBN 9789188899156
}

Omtalt av Svein Mønnesland [professor em. i slaviske språk, Universitetet i Oslo, svein.monnesland@ilos.uio.no]

Det var en gang et land som het Jugoslavia. Hvordan dette landet var? Om det er det delte meninger. Mange har gitt sitt bidrag til skildring av denne staten, ledet av en karismatisk, men diktatorisk president Tito. Det er interessant å undersøke ulike fremstillinger av Jugoslavia i de postjugoslaviske statene, hvordan man etter Jugoslavias sammenbrudd har skildret livet i det sosialistiske Jugoslavia. Boken Det förflutna är ett främmande land bruker et materiale som ikke har vært systematisk undersøkt tidligere, nemlig dokumentarfilmer.

Etter en gjennomgang av de metodiske problemstillingene ved studiet av dokumentarfilm og en oversikt over Jugoslavias historie kommer forfatteren til sakens kjerne, analysen av konkrete filmer. Sanjin Pejković analyserer ni dokumentarfilmer og tv-serier, som han deler inn i tre grupper. Den første er «Tito är död, länge leve Tito». Dette kapitlet gir en grundig innføring i det historiske bildet av Tito - under partisankampen, den stalinistiske perioden, bruddet med Stalin og perioden frem til hans død i 1980. Titos visuelle image forandret seg i takt med utviklingen. Fra å bli fremstilt som en suveren militær leder skiftet fokus over på hans personlige liv som verdensmann og livsnyter. Tito var en karismatisk tyrann, visuelt nærværende overalt, ufeilbar og allvitende. Selv etter Titos død fortsatte den visuelle tilstedeværelsen. Symbolet Tito ble til slutt, ifølge forfatteren, et tomt skall som kunne fylles med hva som helst. "Etter Tito - Tito» var slagordet, og loven forbød nedsettende omtale av hans person og arv. Fra slutten av 1980-tallet kom imidlertid en annen retorikk til syne: Tito som spion, diktator, morder. Nå ble Tito «en ikonisk vattendelare», han ble enten forgudet eller avskydd. Både serbere og kroater fremstilte Tito negativt.

To av de analyserte dokumentarfilmene er laget av kroater, begge omkring 2010-2012. Anton Vrdoljak laget en tv-serie i tolv deler kalt Tito. Filmen er preget 
av kroatisk nasjonalisme. Tito fremstilles som en negativ historisk person, som kroatenes fiende, opptatt av å ødelegge for Kroatia. Pejkovićs analyse viser klart svakhetene ved fremstillingen, og at det er en ideologisk film. Mer nyansert er filmen Tito, the Last Witness of the Testament av Lordan Zafranović. Han har en helt annen og mer positiv holdning til Tito enn Pejković. Filmen består av intervjuer med personer som sto Tito nær, og den blir dermed mer disse personenes oppfatning enn en direkte dokumentar om Titos liv. Den tredje Tito-filmen er Želimir Žilniks Tito for annen gang blant serberne fra 1994, hvor han lar en skuespiller opptre som Tito på gaten i Beograd. Selv om folk vet at Tito er død, er det nesten som de tror han har gjenoppstått, og de fører samtaler med ham om problemene de har. Bildet av Tito er nyansert, men filmen sier mer om den turbulente tiden Serbia stod oppe i, og om folks forvirring.

Det neste kapitlet i boken handler om «minneskonflikter», jugoslavisk popkultur og jugoslavisk filmhistorie. Her blir begrepet jugonostalgi analysert. Filmserien Warehouse av Igor Stolmenov viste i 29 episoder ulike sider ved det sosialistiske Jugoslavia, alt i en nostalgisk tone. Særlig 1960- og 1970-tallet fremstilles som en gullalder. Regissørens hensikt er å vise yngre generasjoner hva som bandt jugoslavene sammen den gangen, som et grunnlag for fortsatt samhold. Pejković kritiserer med god grunn filmen for å være overflatisk og unngå å ta opp hvorfor dette idealsamfunnet kunne ende i oppløsning og krig. Ved bare å fokusere på det nostalgiske og idealiserte blir det en historieforfalskning. Nasjonalismens fremvekst blir helt uforståelig. Et avsnitt i serien handler om rockegruppen Bijelo Dugme, ledet av Goran Bregović, som eksisterte fra 1974 til 1989. Gruppen symboliserte Jugoslavia på en måte som regimet stort sett aksepterte. Med musikalske innslag fra ulike landsdeler og kombinasjonen av folkemusikk og urban rock var gruppen genuint jugoslavisk. Typisk nok gikk gruppen i oppløsning omtrent samtidig med staten.

En lang sekvens handler om jugoslavisk filmhistorie. Filmen Prohibited Without Prohibition handler om jugoslavisk filmproduksjon på 1960- og 1970-tallet og den politiske selvsensuren. Mest inngående analyserer Pejković filmen Cinema Komunisto av Mila Turajlić (2010), en film som er blitt vist mye også i utlandet. I sentrum står det statlige filmselskapet Avala film, «Jugoslavias Hollywood». Ifølge Turajlić ble film brukt for å skape en myte og falsk historie, preget av kommunistisk propaganda. Pejković er svært kritisk til denne filmen, og mener at den i altfor stor grad fremstiller den jugoslaviske filmproduksjonen som underlagt Partiet og Tito selv. Det er nok riktig at Tito var opptatt av film, ikke minst filmer om seg selv, men en detaljstyring av all filmproduksion avvises. En rekke filmer fra denne perioden som ikke passer inn iTurajlićs påstand om kommunistisk propaganda, blir ikke nevnt i hennes fremstilling.

Det tredje kapitlet i boken heter «Subjektiva sanningar» og omfatter det forfatteren kaller essayfilmer - filmer som ser jugoslavisk fortid gjennom personlige minner, og filmer de selv laget under Jugoslavia-tiden. Her analyseres blant annet. Dušan Makavejevs A Hole in the Soul fra 1994. Makavejev hadde opplevd at hans 
film W. R. - Kroppens mysterier ble forbudt i hans hjemland (men den var populær i Vesten, riktignok sensurert blant annet i Norge på grunn av sexscener), og han følte seg tvunget til eksil. Hans neste film Sweet Movie måtte produseres i utlandet. Det sier seg selv at hans forhold til Jugoslavia var komplisert. Filmen $A$ Hole in the Soul er en blanding av scener fra Makavejevs liv, hans tidligere filmer og jugoslavisk virkelighet, blant annet ødeleggelsen av broen i Mostar. Filmen er i høyeste grad subjektiv, men gir likevel et sterkt bilde av den jugoslaviske tragedien som førte til at filmskaperen fikk et "hull i sjelen». Makavejevs egen fortid er for ham "et fremmed land».

Boken er en avhandling og inneholder alt som hører til, fotnoter, lister over filmer og litteratur samt teoretiske avsnitt. Forfatteren foretar mange interessante observasjoner og analyser som er verdifulle for alle som er interessert i Jugoslavia. Og så får man lyst til å se (igjen) noen av de filmene som blir analysert. 